STRUČNI ČLANAK

\author{
Tatjana Živković
}

\title{
POJAM INSPEKCIJSKOG NADZORA U OBLASTI ZAŠTITE ŽIVOTNE SREDINE
}

\begin{abstract}
Apstrakt: Značaj sektora zaštite životne sredine u našoj zemlji postaje sve veći $i$ vidljiviji, posebno imajući u vidu strateško opredeljenje Republike Srbije da se pridruži državama članicama Evropske unije (EU). Da bi se pitanje životne sredine u Republici Srbiji rešilo na održiv način, neophodno je da se donesu zakoni i jedinstvena pravila ponašanja, a svaka organizacija poštovanjem zakona uključi u ostvarivanje ciljeva koji će doprineti održivom razvoju. Nadzor nad sprovođenjem odredaba ovih zakona u svakodnevnoj praksi poveren je inspekciji iz oblasti zaštite životne sredine. $U$ radu se diskutuje o pojmu inspekcijskog nadzora, karakteristikama i ovlašćenjima na osnovu zakonskih propisa vezanih za državnu upravu i zakona u oblasti životne sredine u Republici Srbiji.
\end{abstract}

Ključne reči: Inspekcijski nadzor, životna sredina, zakoni, Republika Srbija.

\section{UVOD}

U skladu sa opredeljenjima međunarodne zajednice, životna sredina zauzima mesto u vrhu svetskih prioriteta. Zakonodavstvo o zaštiti životne sredine vrlo je obimno i obuhvata brojne oblasti, a reguliše kontrolu i zabranu eksploatacije prirodnih resursa, kao i kontrolu zagađenja životne sredine. Vlade zemalja u svetu, bez obzira na društvenopolitički sistem i stepen razvijenosti, utvrđuju i vode politiku zaštite životne sredine i odgovorne su za stanje životne sredine na svojoj teritoriji. Vlade to obezbeđuju radom odgovarajućih organa uprave i stručnih tela koja su dovoljno operativna, kooperativna i interdisciplinarna.

Postavljanje efikasnog sistema upravljanja životnom sredinom zahteva usaglašena načela, razgraničene nadležnosti i savremene i delotvorne upravne mere.

Imajući u vidu strateško opredeljenje Vlade Republike Srbije i države Srbije da se pridruži Evropskom ekonomskom prostoru (EEA) i priključi drža-

* Studentkinja doktorskih studija Pravnog fakulteta Univerziteta Union u Beogradu 
vama članicama Evropske unije (EU), značaj sektora zaštite životne sredine u našoj zemlji postaje sve veći. Sagledavajući pravne tekovine (ACQUIS COMMUNATUIRE) EU, kao dokument koji se mora usvojiti i pretočiti u nacionalno zakonodavstvo, od svih privrednih i vanprivrednih delatnosti poglavlje koje obuhvata oblast zaštite životne sredine je (posle poljoprivrede) najobimnije, najsloženije i investiciono najzahtevnije.

Zato su zakonske obaveze kada je životna sredina u pitanju postale sve značajnije i predstavljaju nezaobilazan faktor za svaku buduću aktivnost. „Da bi se pitanje životne sredine u Republici Srbiji rešilo na održiv način, neophodno je da se donesu zakoni i jedinstvena pravila ponašanja, a svaka organizacija poštovanjem zakona uključi u ostvarivanje ciljeva koji će doprineti održivom razvoju. "1

Najveći broj pravnih normi prava životne sredine pripada upravnom pravu. Razlog za ovakvu konstataciju jeste to da zakoni koji se odnose na zaštitu životne sredine sadrže izvesne preventivne mere i zabrane ili naređuju preduzimanje određenih akcija radi sprečavanja štetnog dejstva pojedinih aktivnosti na životnu sredinu.

Kontrola rada organizacija i drugih subjekata, kada je zaštita životne sredine u pitanju, ostvaruje se i inspekcijskim nadzorom u ovoj oblasti.

Tema ovog rada je usmerena na inspekcijski nadzor, kao jedan od oblika upravno-pravne zaštite, kao deo upravnog nadzora, sa njegovim osnovnim funkcijama, karakteristikama i posebno analiziranim ovlašćenjima i to sa osvrtom na oblast zaštite životne sredine. Inspekcijski nadzor (kontrola) u pravnom sistemu Republike Srbije, kada je zaštita životne sredine u pitanju, značajan je i neophodan deo mehanizma upravljanja, kako na republičkom tako i na svim ostalim nivoima državne uprave.

\section{O INSPEKCIJSKOM NADZORU UOPŠTE}

U svakodnevnoj praksi, pa i stručnoj literaturi, pojmovi inspekcijska kontrola i inspekcijski nadzor često se izjednačavaju, odnosno poistovećuju. Međutim, ovi pojmovi se razlikuju i tako što inspekcijski nadzor kao posao državne uprave podrazumeva nadzor nad tuđim činjenjem ili nečinjenjem bilo da su u pitanju privredna društva, privatni preduzetnici, određena privredna grana ili tehničko-tehnološki sistem, odnosno pojedinac. Kontrola se, naprotiv, odvija unutar određene organizaciono-funkcionalne celine sa različitim ciljem - podizanje i poboljšavanje efikasnosti celine, kvaliteta proizvoda ili usluga, odnosno funkcionalne usklađenosti. Jedina oblast inspekcijskog nadzora koja donekle nosi u sebi pojmovno značenje reči kontrola

1 Đorđe Jovanović, Tatjana Živković, Pregled zakona iz oblasti zaštite životne sredine u Republici Srbiji, Zbornik radova sa savetovanja Metodologija lokalnog ekološkog akcionog plana grada Požarevca, 2009, str. 11. 
jeste upravna inspekcija. Dakle, inspekcijski nadzor usmeren je isključivo na postupanje i ponašanje nadziranog subjekta u odnosu na zakonom propisane mere. Ovim pojmovnim određivanjem jasno se određuju cilj i domet inspekcijskih poslova. $^{2}$

U savremenim uslovima, inspekcijski nadzor predstavlja deo upravnog nadzora, tačnije upravno-pravne delatnosti organa državne uprave i lokalne samouprave. Konstataciju da poslove inspekcijskog nadzora isključivo obavljaju organi državne uprave i lokalne samouprave potvrđuje dosadašnje pravno-teorijsko i legislativno opredeljenje da funkciju inspekcijskog nadzora ne mogu zameniti drugi oblici nadzora. Inspekcijske poslove obuhvataju raznovrsne i posebne upravne i stručno-tehničke radnje. Kao specifičan postupak, inspekcijski nadzor ima sve bitne osobine koje karakterišu nadzor uopšte. Tri faze nadzornog procesa (posmatranje i nadziranje subjekta, davanje ocene o njegovom radu i potrebna, odnosno eventualna intervencija) sadržane su i u inspekcijskom nadzoru. Posebna karakteristika, u odnosu na nadzor uopšte, jeste da se inspekcijskim nadzorom stvara specifičan pravni odnos koji nastaje između nadzornog i nadziranog subjekta. Ova specifičnost je određena njegovim vršiocem nadzora, ovlašćenjima i vrstom akata koje donosi. Inspekcijski nadzor je uvek upravno-pravni odnos, za razliku od nadzora uopšte koji može biti i vanpravni odnos. Za postojanje inspekcijskog nadzora potreban uslov je da bude regulisan pravnim normama, što ga čini pravnim odnosom, a sa druge strane kao nadzorni subjekt uvek se pojavljuje organ državne uprave, čija su ovlašćenja i akti upravnog karaktera, što ga čini upravnim odnosom. Imajuću u vidu da je inspekcijska funkcija usmerena i na zaštitu prava građana i drugih subjekata, kao i okolnost da ovu zaštitu ostvaruju lica sa posebnim ovlašćenjima - inspektori, u posebnom postupku, koristeći veoma široka autoritativna ovlašćenja, zaključuje se da je inspekcijski nadzor jedan od najefikasnijih oblika kontrole i zaštite zakonitosti, a samim tim i zaštite prava građana.

\section{KARAKTERISTIKE INSPEKCIJSKOG NADZORA}

1. Teorijski pojam. Pojam inspekcija u teorijskom smislu podrazumeva dva značenja i to organsko (organizaciono) i funkcionalno (materijalno). Prema organskom shvatanju, inspekcija se definiše, odnosno određuje prema vrsti i nadležnosti organa, kao i prema postupku. Samim tim inspekcija je organizacija, skup organa, po pravilu organa (državne) uprave, koji vrši poslove inspekcijskog nadzora.

2 Igor Vavić, Tatjana Živković, Đorđe Jovanović, Inspekcijski nadzor (kontrola) sa aspekta zaštite životne sredine u Republici Srbiji, Zbornik Eko-Justus I, Pravo i životna sredina, Kopaonik 2008, str. 131-137. 
Prema funkcionalnom shvatanju, inspekcija se određuje prema sadržini nadzorne delatnosti, odnosno sadržini akata koji se donose i radnji koje preduzimaju inspekcijski organi u vršenju nadzorne delatnosti. ${ }^{3}$

Za pojam inspekcijskog nadzora, neophodno je utvrditi i postojanje najmanje dva subjekta. Jedan od njih vrši inspekcijski nadzor (aktivni ili nadzorni subjekat), a drugi trpi taj nadzor (pasivni ili nadzirani subjekat). Po pravilu, nadzor vrši aktivni subjekat posebnom metodom, neposrednim uvidom, koji se sastoji u praćenju, posmatranju, ocenjivanju i mogućem uticaju na aktivnost ili neaktivnost pasivnog subjekta, kako bi se obezbedilo ostvarenje predviđenog cilja. Ovaj cilj se ostvaruje preduzimanjem upravnih i drugih radnji i mera u skladu sa ovlašćenjima, a radi obezbeđenja pravilne primene zakona i drugih propisa i opštih akata. Nasuprot tome, pasivni subjekat trpi nadzor. ${ }^{4}$

Daljom analizom može se utvrditi da inspekcijski nadzor ima više obeležja, od kojih su neka opšta, a neka specifična.

Opšta obeležja inspekcijskog nadzora jesu:

- ima svoje elemente (subjekat, objekat, predmet, ovlašćenje);

- ima specifičan proces koji obuhvata nekoliko faza;

- ostvaruje se različitim sredstvima;

- ima svoj cilj i svrhu.

Posebna obeležja inspekcijskog nadzora jesu:

- vrši se specifičnim metodama;

- ostvaruje se nad aktivnostima nadziranih subjekata;

- ostvaruje se u različitim oblastima;

- vrše ga organi uprave preko posebnih upravnih kadrova - inspektora.

2. Legislativni pojam. Analizom pozitivnopravnog određenja ove vrste nadzora konstatuje se da inspekcijski nadzor, kao vrsta upravnog nadzora, predstavlja sredstvo kojim organi državne uprave ispituju sprovođenje zakona i drugih propisa neposrednim uvidom u poslovanje i postupanje fizičkih i pravnih lica i, zavisno od rezultata nadzora, izriču mere na koje su ovlašćeni. ${ }^{5}$

U primeni ovlašćenja i dužnosti, inspekcijski nadzor uopšte regulisan je i Zakonom o opštem upravnom postupku koji sadrži osnovna načela ${ }^{6}$ koja inspektor prilikom vršenja inspekcijskog nadzora uvek može da primeni u

3 Đorđe Blažić, Prilog teoriji o inspekcijskom nadzoru, Pravni život, Beograd 1995, str. 809.

$4 \quad$ Ibid., str. 811.

5 Zakon o državnoj upravi, „Službeni glasnik RS“, br. 79/05, 101/07, 95/10.

6 Član 6. (Načelo zaštite prava građana i zaštite javnog interesa), član 7. (Načelo efikasnosti), član 8. (Načelo istine), „Službeni list SRJ“, br. 33/97, 31/01 i „Službeni glasnik RS“, br. 30/10. 
slučaju nedostatka materijalnog propisa ili postojanja dileme u vezi sa primenom nekog pozitivnog propisa.

Polazeći od teorijskog i pozitivnopravnog određenja inspekcijskog nadzora, mogla bi se dati sveobuhvatna definicija koja glasi da je: inspekcijski nadzor upravno-pravni odnos izmedu subjekata inspekcijskog nadzora, u kojem aktivni subjekat, kao vršilac nadzora (inspektor), posebnim metodama (inspekcijskim pregledom) posmatra, prati i ocenjuje, a po potrebi i utiče na (ne)aktivnosti nadziranog subjekta preduzimanjem upravnih $i$ drugih mera $i$ radnji $u$ skladu sa ovlašćenjima, a u cilju obezbeđenja pravilne primene zakona, drugih propisa i opštih akata.

Ovakvo teorijsko i legislativno stanovište nameće pitanje svrhe i cilja inspekcijskog nadzora. Iako ovo pitanje može biti posmatrano sa više aspekata, sigurno je da je osnovna svrha inspekcijskog nadzora da se ostvare rezultati koje je inspekcijski organ imao u vidu prilikom započinjanja inspekcijskog nadzora, koji su u njegovom, odnosno državnom interesu, a pre svega u cilju zakonitosti i zaštite prava građana.

\section{INSPEKCIJSKA OVLAŠĆENJA}

Ne ulazeći u dublju analizu pojedinačno navedenih opštih i posebnih obeležja inspekcijskog nadzora, neophodno je da se posebno naglase i analiziraju inspekcijska ovlašćenja.

Ovlašćenja su bitan uslov, jedan od najznačajnijih elemenata inspekcijskog nadzora, koja čine skup mera i aktivnosti inspekcijskih organa kojima oni utiču na rad i postupanje, ponašanje nadziranih subjekata. Inspekcijska ovlašćenja predstavljaju izvesnu sposobnost inspektora da utiču na aktivnosti nadziranih subjekata u cilju usklađivanja sa propisima njihovog rada i postupanja.

Ovakva definicija podrazumeva bliža određenja, odnosno nekoliko važnih karakteristika koje zaslužuju preciznije objašnjenje. Naime, inspekcijska ovlašćenja primenjuju se u trećoj fazi nadzornog procesa, u intervenciji inspekcije, odnosno ona se koriste samo u slučajevima kada se u postupku inspekcijskog nadzora utvrde nepravilnosti u radu i postupanju nadziranog subjekta.

Dalje, ova ovlašćenja su obligatornog, odnosno obaveznog karaktera, a ne fakultativnog. To znači da kada inspektor utvrdi povrede zakona ili drugog propisa, dužan je da upotrebi svoja ovlašćenja i ne može ocenjivati da li će ih upotrebiti ili ne. Ova obaveznost u upotrebi ovlašćenja proizlazi iz njegove posebne odgovornosti koja je regulisana zakonom. ${ }^{7}$

7 Zakon o državnoj upravi, član 24. stav 3. al. 1. i 2, propisuje da je inspektor posebno odgovoran ako: u vršenju nadzora ne preduzme, ne predloži ili ne odredi meru za 
Kao još jednu od važnih karakteristika treba istaći da se u postupku nadzora koriste ona inspekcijska ovlašćenja koja na najefikasniji način postižu cilj i svrhu inspekcijskog nadzora. I na kraju, inspekcijska ovlašćenja mogu da koriste samo inspektori.

Ovlašćenja inspekcija se mogu posmatrati i sa različitih aspekata, odnosno u zavisnosti od njihove sadržine, karaktera i dejstva.

1. S obzirom na njihovu sadržinu, ovlašćenja mogu biti:

- autoritativna $\mathrm{i}$

- neautoritativna.

2. S obzirom na karakter, mogu biti:

- procesno-pravnog i

- materijalno-pravnog karaktera.

3. S obzirom na njihovo dejstvo, ovlašćenja mogu biti:

- preventivna

- represivna i

- korektivna.

Autoritativna ovlašćenja inspekcija podrazumevaju mogućnost inspektora da, putem upravnih akata i upravnih radnji, nadziranog subjekta usmeri da svoj rad i ponašanje koriguje u propisanom pravcu. U ovu grupu ovlašćenja spadaju korektivna i represivna ovlašćenja.

Prema procesno-pravnom karakteru, ovlašćenja inspekcije podrazumevaju da inspektor pokreće i vodi inspekcijski postupak, odnosno sprovodi sve radnje upravnog postupka usmerene na utvrđivanje činjeničnog stanja, tako da se ova vrsta ovlašćenja ostvaruje prilikom posmatranja, odnosno praćenja i ocenjivanja rada nadziranog subjekta, koje se ostvaruje u prve dve faze nadzornog procesa.

Pod materijalno-pravnim ovlašćenjima podrazumevaju se ovlašćenja inspektora da donosi upravno-pravne akte i vrši upravno-pravne radnje kojima se utiče na rad i postupanje, ponašanje nadziranog subjekta. Ova vrsta ovlašćenja ostvaruje se u trećoj fazi nadzornog postupka ili fazi intervencije.

Preventivna ovlašćenja. Skup upravnih mera i radnji inspekcija, kojima se sprečava nezakonitost u radu i postupanju nadziranih subjekata, predstavlja preventivna ovlašćenja koja su najslabiji oblik zaštite jer ne poseduju dovoljnu autoritativnost. Ona se najčešće ostvaruju kao predlog, inicijativa, ukazivanje, izdavanje instrukcija, stručnih uputstava koja se koriste najčešće u toku inspekcijskog nadzora, a veoma retko i pre njegovog vršenja. Preventivna ovlašćenja pre inspekcijskog nadzora ostvaruju se kao prethodna saglasnost,

koju je ovlašćen; ako ne predloži ili ne pokrene postupak pred nadležnim organom zbog utvrđenih nezakonitosti, odnosno nepravilnosti. 
odobrenje ili davanje stručnih uputstava, kao na primer izdavanje određene saglasnosti za otvaranje i početak rada određenih delatnosti.

Korektivna ovlašćenja. Skup upravnih mera i radnji inspekcija kojima se utiče na promenu rada i postupanja nadziranih subjekata u cilju korigovanja njihovog dotadašnjeg rada i postupanja i usaglašavanja sa zakonom i drugim propisima predstavljaju korektivna ovlašćenja koja zbog svoje autoritativnosti predstavljaju efikasnu zaštitu.

Najčešća, najkarakterističnija korektivna ovlašćenja su svakako nalozi, naredbe za preduzimanje odgovarajućih mera i radnji radi otklanjanja utvrđenih nepravilnosti. Korektivna ovlašćenja dobijaju svoj realni oblik u upravnim aktima - rešenjima, kojima se naređuje nadziranom subjektu da uskladi svoj rad i postupanje prema pozitivnim propisima. U odnosu na nadziranog subjekta, ova vrsta ovlašćenja, pored korektivne svrhe, ima i karakter represije kada se imaju u vidu posledice koje nadzirani subjekat trpi njihovim izvršenjem.

Represivna ovlašćenja. Skup upravnih mera i radnji inspekcija, pod kojima se po pravilu podrazumevaju sankcije zbog nepridržavanja zakona i drugih propisa prema nadziranim subjektima, predstavljaju represivna ovlašćenja i dele se na neposredna i posredna. Zabrane, kazne ili zaštitne mere najčešći su oblik neposrednih represivnih ovlašćenja koje ima inspektor, dok se posredna represivna ovlašćenja manifestuju u vidu prijava, zahteva ili predloga.

Neposredna represivna ovlašćenja najčešće se izražavaju u vidu izricanja zabrane obavljanja delatnosti, zabrane upotrebe sredstava rada, opreme i uređaja, pogona, izricanja mandatne kazne, privremenog oduzimanja i uništavanja neispravnih predmeta i sredstava kojima je učinjeno krivično delo, privredni prestup ili prekršaj itd.

Najkarakterističnija posredna represivna ovlašćenja jesu zahtev za pokretanje prekršajnog postupka, prijava za privredni prestup, prijava za krivično delo i zahtev za brisanje obavljanja delatnosti privrednog subjekta iz registra privredne delatnosti.

Represivna ovlašćenja su složenog karaktera jer zbog svoje prirode predstavljaju najefikasniji i u isto vreme najautoritativniji oblik zaštite prava, i to iz više razloga. Najpre, pored svoje represivne funkcije, ova ovlašćenja u sebi sadrže i preventivni i korektivni karakter. Preventivni karakter se ogleda u sprečavanju daljeg nezakonitog rada i postupanja, ponašanja nadziranog subjekta, ali i ostalih subjekata prema kojima nisu preduzete represivne mere, ali koji podležu inspekcijskom nadzoru i prema kojima se takođe mogu preduzeti ova ovlašćenja, što predstavlja takozvanu specijalnu i generalnu prevenciju.

Korektivni karakter ovih ovlašćenja ogleda se u uticaju ovih mera na korekciju dotadašnjeg rada i postupanja nadziranih subjekata i potrebe njegove promene ubuduće. 
Treba napomenuti da između pojedinih navedenih ovlašćenja ne postoje jasne granice razgraničenja, tako da u zavisnosti od njihovog posmatranja neka od njih mogu biti i korektivna i preventivna. Samim tim od vrste ovlašćenja zavisi i stepen zaštite prava građana. Tako se preventivnim ovlašćenjima obezbeđuje manji stepen ove zaštite, a korektivnim i represivnim, kao autoritativnim, obezbeđuje se veći i efikasniji sistem zaštite.

Kada je u pitanju zaštita prava koja se ostvaruju inspekcijskim nadzorom, ovlašćenja inspekcije sprovode se putem generalnih i posebnih ovlašćenja.

Sistemskim zakonima u upravi uređuju se generalna ovlašćenja i to $u$ okviru posebnih odredaba o inspekcijskom nadzoru. ${ }^{8}$

Generalna ovlašćenja može koristiti svaki inspektor, bez obzira na to da li su ona predviđena posebnim zakonima, jer kao takva pružaju sasvim dovoljno prostora za efikasnu zaštitu. Pri tome treba imati u vidu da će u vršenju inspekcijskog nadzora inspektor koristiti samo ona generalna ovlašćenja kojima se efikasnije ostvaruje inspekcijski nadzor i koja odgovaraju prirodi inspekcijskog nadzora.

Posebna ovlašćenja inspekcija, za razliku od generalnih, utvrđuju se specijalnim zakonima za različite inspekcije. Osnovna karakteristika utvrđivanja ovih ovlašćenja specijalnim zakonima jeste njihova preciznost i razrađenost, koja je regulisana u poglavljima „nadzor“ (inspekcijski nadzor, prava i dužnosti inspektora, ovlašćenja inspektora). Ovako definisana posebna ovlašćenja trebalo bi da omoguće efikasno vršenje inspekcijskog nadzora.

\section{OvLAŠĆENJA INSPEKCIJE PREMA ZAKONIMA IZ OBLASTI ZAŠTITE ŽIVOTNE SREDINE}

Materija prava životne sredine u Republici Srbiji uređena je velikim brojem zakonskih i podzakonskih akata. Važeći zakoni se mogu podeliti na četiri opšta, sistemska zakona koji regulišu opšta pitanja koja se odnose na zaštitu životne sredine u celini, i to su: Zakon o zaštiti životne sredine, ${ }^{9}$ Zakon o proceni uticaja na životnu sredinu, ${ }^{10}$ Zakon o integrisanom sprečavanju i kontroli zagađivanja životne sredine ${ }^{11}$ i Zakon o strateškoj proceni uticaja na životnu sredinu. ${ }^{12}$ Godine 2009 , doneto je više posebnih, sektorskih zakona koji sadrže pravila o upotrebi i zaštiti pojedinih dobara, čime je upotpunjena

8 Član 93. Zakona o državnoj upravi, „Službeni glasnik RS“, br. 79/05, 101/07, 95/10.

9 „Službeni glasnik RS“, br. 135/04, 36/09, 72/09.

10 „Službeni glasnik RS“, br. 135/04, 36/09.

11 „Službeni glasnik RS“, br. 135/04.

12 „Službeni glasnik RS“, br. 135/04, 88/10. 
zaštita životne sredine i izvršena harmonizacija propisa naše zemlje sa propisima Evropske unije. ${ }^{13}$

Prema Zakonu o državnoj upravi i Zakonu o opštem upravnom postup$\mathrm{ku}$, ako se podsetimo na podelu ovlašćenja, inspektor za zaštitu životne sredine primenjuje generalna ovlašćenja (opšta), a koja važe za sve oblasti i za sve inspektore.

Ali, prema zakonima iz oblasti zaštite životne sredine, inspektori primenjuju i posebna ovlašćenja koja sadrže sve već navedene i opisane karakteristike, a tipična su samo za ovu oblast.

Veoma je važno navesti oblasti u kojima se vrši inspekcijski nadzor, jer se samo tako može sagledati obimnost, složenost i značaj propisa koji regulišu životnu sredinu. Inspekcijski nadzor se vrši u oblastima:

- kontrole zagađenja vazduha;

- postupanja sa opasnim materijama;

- zaštite od jonizujućeg zračenja;

- zaštite od nejonizujućeg zračenja;

- postupanja sa otpadom;

- integrisanog sprečavanja i kontrole zagađivanja životne sredine;

- zaštite od buke;

- planiranja i izgradnje objekata koji mogu imati značajan uticaj na životnu sredinu;

- kontrole zaštićenih prirodnih dobara;

- zaštite i korišćenja ribolovnih voda;

- kontrole osnovnih geoloških istraživanja, a za podzemne vode i detaljnih podzemnih radova;

- zaštite i korišćenja prirodnih resursa (vode, zemljište, šume);

- kontrole međunarodnog prometa vrstama koje se nalaze na cites listama;

- prirodnih retkosti;

- ribolovnih voda, proizvodnje ribe i riblje mlađi;

- kontrole obavljanja ribolova, alata za obavljanje ribolova i vremena lovostaja riba.

13 Zakon o ambalaži i ambalažnom otpadu, „Službeni glasnik RS“, br. 36/09, Zakon o zaštiti od nejonizujućeg zračenja, „Službeni glasnik RS“, br. 36/09, Zakon o zaštiti od jonizujućeg zračenja, „Službeni glasnik RS“, br. 36/09, Zakon o zaštiti od buke u životnoj sredini, „Služebni glasnik RS“, br. 36/09, 88/10, Zakon o zaštiti vazduha, „Službeni glasnik RS“, br. 36/09, Zakon o biocidnim proizvodima, „Službeni glasnik RS“, br. 36/09, 88/10, Zakon o zaštiti prirode, „Službeni glasnik RS“, br. 36/09 i 88/10, Zakon o zaštiti i održivom korišćenju ribljeg fonda, „Službeni glasnik RS“, br. 36/09, Zakon o hemikalijama, „Službeni glasnik RS“, br. 36/09, 88/10, Zakon o upravljanju otpadom, „Službeni glasnik RS“, br. 36/09, 88/10. 


\section{ZAKLJUČAK}

Rešavanje pitanja životne sredine na održiv način u Republici Srbiji podrazumeva donošenje zakona i jedinstvenih pravila ponašanja. - Poštovanjem ovih zakona svaki subjekat učestvuje u ostvarivanju ciljeva koji će doprineti održivom razvoju, čime se ispunjava jedan od uslova pridruživanja Evropskoj uniji (EU). Na osnovu prikazanih karakteristika inspekcijskog nadzora zaključuje se da je u našem pozitivnom zakonodavstvu jedino i samo inspekcija ovlašćena da kontroliše primenu zakonskih propisa. Sledstveno tome, inspekcija za zaštitu životne sredine je ovlašćena da kontroliše primenu svih zakonskih propisa vezanih za ovu oblast, a korišćenjem navedenih inspekcijskih ovlašćenja ostvaruje i cilj inspekcijskog nadzora. Primenom pomenutih odredaba Zakona o državnoj upravi i zakona iz oblasti životne sredine ovaj cilj se ostvaruje u vidu prevencije zagađivanja, prevencije eksploatacije ekomedija i boljeg kvaliteta životne sredine u Republici Srbiji uopšte. Na kraju, potrebno je posebno sagledati i neophodnost razvoja kapaciteta inspekcije, $s$ obzirom na povećanje njenih obaveza u ovoj oblasti. 